EWA KuRANTOWICZ

Dolnośląka Szkota Wyższa we Wroctawiu

\author{
AdRIANNA NiZIŃSKA \\ Uniwersytet w Goeteborgu \\ Teresa Padilla-Carmona \\ José GonZÁlez-Monteagudo
}

Uniwersytet $w$ Sewilli

\title{
UNIWERSYTET I PRACODAWCY W POLSCE I HISZPANII. KONFRONTACJE, OCZEKIWANIA, PERSPEKTYWY
}

\begin{abstract}
Aвstract. Kurantowicz Ewa, Nizińska Adrianna, Padilla-Carmona Teresa, González-Monteagudo José, Uniwersytet i pracodawcy w Polsce i Hiszpanii. Konfrontacje, oczekiwania, perspektywy [University and Employers in Poland and Spain. Confrontations, Expectations, Perspectives]. Studia Edukacyjne nr 44, 2017, Poznań 2017, pp. 23-43. Adam Mickiewicz University Press. ISSN 1233-6688. DOI: 10.14746/se.2017.44.2

This paper is based on the partial results of EMPLOY research project. We present the Polish and Spanish employers' perspectives, experiences and needs when it comes to the HE graduates. Before the empirical analyses we compare the political and cultural contexts of employability in both countries as also provide the review of the main Polish and Spanish research reports in this field.
\end{abstract}

Key words: employability, employers, higher education, non-traditional student

Związki między europejskimi uniwersytetami a rynkiem pracy i szeroko rozumianą sferą gospodarki stały się $\mathrm{w}$ ostatnich latach przedmiotem zainteresowania badaczy oraz areną proponowanych, a niekiedy narzucanych odgórnie reform i wpisanych w neoliberalną logikę eksperymentów społecznych, w których aktywną rolę odgrywało także państwo oraz makrostruktury supranarodowe. Problematyka zatrudnialności ${ }^{1}$, jako jeden z kluczowych

\footnotetext{
${ }^{1}$ Zatrudnialność (employability) - opierając się na definicji z 2009 roku, sformułowanej przez Working Group on Employability (Raport EURYDICE 2014, s. 62), można stwierdzić, że jest to
} 
celów procesu bolońskiego i koncepcja zmiany ról oraz relacji uniwersytetów i rynku pracy uplasowały się $\mathrm{w}$ centrum zainteresowania politycznego Unii Europejskiej (Europejskie Szkolnictwo Wyższe w 2012: Raport z wdrożenia procesu bolońskiego), dając początek zmianom legislacyjnym, organizacyjnym i strukturalnym $w$ uniwersytetach europejskich. Procesy te, zarówno naturalizowane i technicyzowane, jak i kontestowane czy ujmowane w perspektywie krytycznej, stały się także przedmiotem zainteresowania badaczy, wywodzących się z wielu dyscyplin.

Europejskie analizy losów absolwentów na rynkach pracy wskazywały nie tylko na różnice pomiędzy poszczególnymi państwami (zróżnicowane modele kształcenia uniwersyteckiego, odmienna sytuacja ekonomiczna), ale na strukturalne trudności doświadczane w całej Europie przez absolwentów nietradycyjnych, wywodzących się ze środowisk defaworyzowanych. Międzynarodowy projekt badawczy EMPLOY², którego wyniki cząstkowe stanowią kanwę niniejszego artykułu, skupia się właśnie na tym aspekcie, proponując nową perspektywę oraz wgląd w związki między zatrudnialnością a kompetencjami studentów nietradycyjnych ${ }^{3}$. Badania pokazują, że wejście na rynek pracy może być szczególnie trudne dla tej grupy. Zwykle trwa ono dłużej niż w przypadku studentów tradycyjnych, występuje także zwiększone ryzyko podejmowania pracy poniżej posiadanych kwalifikacji, co zmniej-

zdolność absolwentów do zdobycia znaczącego dla nich zatrudnienia lub samozatrudnienia, utrzymania tego zatrudnienia i identyfikowania na rynku pracy szans dla rozwoju własnej kariery zawodowej.

${ }^{2}$ Projekt EMPLOY jest finansowany ze środków programu Erasmus+ (2014-1-UK01-KA203001842-TP) i realizowany przez sześć uniwersytetów - Uniwersytet w Warwick (Wielka Brytania), lider projektu, Dolnośląska Szkoła Wyższa (Polska), Uniwersytet w Sztokholmie (Szwecja) Uniwersytet Algarve (Portugalia) Uniwersytet w Sewilli (Hiszpania) oraz Narodowy Uniwersytet Irlandii, Maynooth (Irlandia). Głównym celem projektu EMPLOY jest poprawa skuteczności wejścia na rynek pracy absolwentów poprzez wypracowanie takich narzędzi, jak: katalog dobrych praktyk uczelni w dziedzinie wzmacniania i zwiększania zatrudnialności absolwentów oraz model doradztwa poprawiającego i wzmacniającego zatrudnialność studentów/absolwentów nietradycyjnych. Narzędzia powstaną na podstawie wyników badań biograficznych prezentujących głosy studentów, absolwentów, pracowników uczelni i pracodawców, ich doświadczenia oraz postrzeganie zatrudnienia i zatrudnialności: http: www.employ.dsw.edu.pl

${ }^{3}$ Studenci nietradycyjni - których dostęp do szkolnictwa wyższego jest utrudniony - stanowią grupy niedoreprezentowane na tle dominujących uprzednio w Europie przedstawicieli klasy średniej. Pojawili się wraz z rozwojem masowego systemu szkolnictwa wyższego w całej Europie. W projekcie EMPLOY definiowani są jako wywodzący się z rodzin o niskim statusie socjoekonomicznym, pochodzą z grup niedoreprezentowanych w szkolnictwie wyższym, są studentami dojrzałymi, osobami z niepełnosprawnościami lub reprezentują pierwsze pokolenia w szkolnictwie wyższym w swych rodzinach (patrz także: E. Kurantowicz, A. Nizińska, Equality and improving retentions practices for non-traditional students in Poland, [w:] Student Voices on Inequalities in European Higher Education, red. F. Finnegan, B. Merrill, C. Thunborg, London - New York 2014; M. Czubak-Koch i in., Między uniwersytetem a światem pracy. Tranzycje w narracjach studentów polskich i hiszpańskich, Dyskursy Młodych Andragogów, 2017, 18). 
sza znaczenie tego doświadczenia dla dalszego rozwoju kariery zawodowej. Często dochodzi również do rozdźwięku między umiejętnościami absolwentów a oczekiwaniami pracodawców.

\section{Szkoły wyższe a rynek pracy w Polsce i Hiszpanii - główne trendy}

Zarówno w Polsce, jak i w Hiszpanii trudno wskazać odrębne dane statystyczne, analizy, prognozy, czy raporty dotyczące studentów bądź absolwentów nietradycyjnych, zdefiniowanych $\mathrm{w}$ kategoriach przyjętych przez badaczy w projekcie. Pojawiały się działania adresowane do wybranych grup, takich jak studenci dojrzali, osoby z niepełnosprawnościami, czy przedstawiciele mniejszości etnicznych. Jednak całościowe ujęcie czy wskazanie jednolitych strategii z poziomu makro, adresowanych do nietradycyjnych studentów i absolwentów nie było możliwe z uwagi na fragmentaryczny charakter danych. Jeśli chodzi o polskich studentów i absolwentów, w perspektywie makro najważniejszymi podmiotami wpływającymi na edukacyjne oraz zawodowe ścieżki i prowadzącymi sektorowe działania były przede wszystkim Ministerstwa: Nauki i Szkolnictwa Wyższego oraz Pracy i Polityki Społecznej. Kreowany przez te podmioty dyskurs oraz instrumenty legislacyjne miały znaczący wpływ na funkcjonowanie szkół wyższych oraz budowanie relacji z rynkiem pracy. Doskonale obrazują to między innymi założenia wieloletnich reform w szkolnictwie wyższym, prowadzonych od 2011 roku.

Dynamicznemu rozwojowi polskiego szkolnictwa wyższego, toczącego się od ponad dekady, a zainicjowanemu przez przemiany systemowe nie towarzyszyły odpowiednie zmiany o charakterze jakościowym, choć szybko dostrzeżono konieczność zmian w systemowym podejściu do procesu kształcenia uniwersyteckiego, prowadzonego na masową skalę (pięciokrotne zwiększenie liczby studentów). Ważnym czynnikiem były też zobowiązania podjęte w ramach członkostwa Polski w Unii Europejskiej i wprowadzania procesu bolońskiego w szkolnictwie wyższym.

Już w roku 2007 analizy OECD wskazywały na konieczność rozpoczęcia wielopoziomowego procesu modernizacji w polskim szkolnictwie wyższym. Wiele z nich odnosiło się do słabego powiązania programów kształcenia z rynkiem pracy oraz niskiego poziomu zaangażowania uniwersytetów w kształcenie dalsze w ramach doskonalenia zawodowego i "trzecią misję" skupioną na realizacji usług edukacyjnych dla podmiotów zewnętrznych, ekspertyz, czy szkoleń zamawianych ${ }^{4}$. Wdrożenie re-

${ }^{4}$ OECD 2007, Poland must accelerate reform of tertiary education, http://www.oecd.org/poland/polandmustacceleratereformoftertiaryeducationoecdsays.htm. 
form szkolnictwa wyższego rozpoczęło się w 2011 roku, po trzech latach negocjacji z partnerami społecznymi i interesariuszami. Reforma koncentrowała się na zdefiniowanych uprzednio deficytach, takich jak: brak projakościowego mechanizmu finansowania szkolnictwa wyższego, niski poziom umiędzynarodowienia, niewłaściwe struktury programów kształcenia, skomplikowany i mało czytelny system awansów naukowych, brak umiejętności zarządzania uniwersytetami oraz słabe powiązanie szkół wyższych z rynkiem pracy. Drugi etap doskonalenia kontynuowano w reformach przeprowadzanych od roku 2014. W odniesieniu do zdiagnozowanego przez OECD słabego powiązania kształcenia z rynkiem pracy podjęto liczne działania wynikające $\mathrm{z}$ wytycznych wdrażania procesu bolońskiego i komunikatu bukaresztańskiego. Proces boloński już od samego początku koncentrował się na wzmacnianiu zatrudnialności absolwentów europejskich uniwersytetów, a jednym z jego celów było zwiększenie konkurencyjności, modernizacja i ujednolicenie struktur tytułów nadawanych absolwentom oraz wzmocnienie mechanizmów zapewniania jakości, mając na uwadze wspólny rynek krajów unijnych.

Z kolei w komunikacie bukaresztańskim (2012) sformułowano następujące priorytety dla szkolnictwa wyższego w Europie: wzmacnianie zatrudnialności absolwentów, skuteczne wdrożenie efektów kształcenia w programach studiów oraz kontynuacja spójnego wdrażania reform strukturalnych, zapoczątkowanych przez proces boloński (krajowe ramy kwalifikacji, potwierdzanie efektów uczenia się, zapewnianie jakości kształcenia). Podkreślano również konieczność poprawy jakości współpracy uniwersytetów z pracodawcami, szczególnie w obszarze projektowania i doskonalenia programów kształcenia, które miały zostać wzbogacone o efekty kształcenia wzmacniające innowacyjność, przedsiębiorczość oraz potencjał badawczy absolwentów. Priorytety te znalazły bezpośrednie przełożenie $\mathrm{w}$ kolejnych falach reform szkolnictwa wyższego w Polsce - przyjęto, iż zaangażowanie pracodawców, związków zawodowych i branżowych oraz stowarzyszeń biznesowych $\mathrm{w}$ projektowanie, realizowanie i doskonalenie programów kształcenia jest skutecznym mechanizmem komunikacji uniwersytetów z rynkiem pracy oraz przekazywania sygnałów ze świata pracy bezpośrednio na wyższe uczelnie. Uczelnie zostały zobowiązane do angażowania interesariuszy zewnętrznych we wszystkie elementy procesu dydaktycznego oraz do powoływania ciał decyzyjnych i kontrolnych, w skład których wchodzili przedstawiciele świata pracy. Wśród innych rozwiązań systemowych, wprowadzonych w ramach reformy, a nastawionych głównie na wzmocnienie powiązań uczelni z rynkiem pracy, należy wskazać następujące:

- zróżnicowanie oferty edukacyjnej i wprowadzenie kształcenia profilowanego, z podziałem na profil ogólnoakademicki, przygotowujący do pracy 
badawczej i naukowej oraz profil praktyczny, zorientowany na umiejętności i kompetencje ściśle powiązane z rynkiem pracy;

- zwiększenie wymiaru obligatoryjnych praktyk na profilach praktycznych do 3 miesięcy;

- zaangażowanie ekspertów zewnętrznych (bez stopni naukowych, ale ze znaczącymi osiągnięciami zawodowymi w swojej branży) w proces kształcenia i powierzenie im roli nauczycieli akademickich (tzw. praktycy). Reforma z 2014 roku wprowadziła także możliwość zatrudniania praktyków i wliczania ich do minimum kadrowego niezbędnego do prowadzenia kierunku studiów;

- wprowadzenie możliwości realizacji połowy programu kształcenia w miejscu pracy, we współpracy z przedsiębiorstwem lub innym podmiotem gospodarczym (tzw. studia dualne $)^{5}$;

- zobowiązanie wyższych szkół zawodowych do powoływania konwentów, złożonych z przedstawicieli władz lokalnych i zrzeszeń przedsiębiorców;

- badanie losów absolwentów (scedowane w kolejnych fazach reformy na państwo i jego jednostki, takie jak ZUS czy GUS) oraz powołanie rzecznika praw absolwentów;

- rozwój akademickich biur karier6.

Inne działania związane z poprawą wskaźników zatrudnialności zostały podjęte w porozumieniu z Ministerstwem Pracy i Polityki Społecznej. Dotyczyły one deregulacji wybranych profesji, do których dostęp był chroniony przez korporacje zawodowe, w odpowiedzi na obniżone wskaźniki zatrudnialności dla pewnych zawodów, do których dostęp uznano za przeregulowany. Analizy rządowe wskazywały, iż zawyżone wymogi kwalifikacyjne w odniesieniu do niektórych branż powodowały strukturalne bariery w dostępie do zawodów, obwarowanych przedłużonymi praktykami, stażami, dodatkowymi egzaminami, kosztownymi kursami kwalifikacyjnymi itp. Działania w ramach tzw. pakietu deregulacyjnego, otwierającego dostęp do wybranych zawodów, prowadzone były we współpracy z rzecznikiem praw absolwenta, który prezentował przejście ze świata uczelni do świata pracy w perspektywie absolwentów.

O ile reformy szkolnictwa wyższego w Polsce koncentrowały się na wprowadzeniu mechanizmów kontroli jakości do umasowionego gwałtownie szkolnictwa wyższego, by tym samym przyczynić się do zwiększenia jakości dyplomów absolwentów, Hiszpania w odpowiedzi na sytuację ekonomiczną podejmowała działania dążące do zwiększenia współczynni-

\footnotetext{
${ }^{5}$ Kolejne zmiany w przepisach z 2017 roku wprowadziły także doktoraty wdrożeniowe.

${ }^{6}$ EHEA 2012, Bucharest Communiqué: Making the Most of Our Potential: Consolidating the European Higher Education Area 26-27 April 2012; https://media.ehea.info/file/2012_Bucharest/67/3/Bucharest_Communique_2012_610673.pdf.
} 
ków skolaryzacji. W świetle raportu hiszpańskiego Ministerstwa Edukacji, Kultury i Sportu z 2014 roku, Hiszpania przodowała w rankingu państw OECD o najwyższym współczynniku ludności, która kończy edukację na etapie obowiązkowej szkoły średniej lub poniżej tego pułapu (45\% dorosłych pomiędzy 25. a 64. r.ż., podczas gdy średnia dla krajów OECD wynosi $24 \%)$. W okresie gwałtownego wzrostu gospodarczego, tuż przed kryzysem 2008 roku, obserwowano gwałtowne obniżenie czynników skolaryzacyjnych w Hiszpanii. Młodzi ludzie szybko porzucali szkołę na rzecz dobrze płatnych prac $\mathrm{w}$ przemyśle budowalnym czy turystycznym, gdzie nie wymagano od nich formalnych kwalifikacji. W konsekwencji kryzysu, trend ten uległ jednak odwróceniu i okres przejścia na rynek pracy znacząco się wydłużył na rzecz podejmowania kształcenia i dodatkowych szkoleń. Między rokiem 2000 a 2012 liczba studentów wzrosła o 5\%, a także odnotowano znaczący wzrost zainteresowania edukacją ponadobowiązkową. Nadal jednak liczne analizy wskazywały na strukturalne słabości systemowe, prowadzące do bezrobocia młodzieży hiszpańskiej. Według Lenarta i innych7, wśród najważniejszych trendów kreujących to zjawisko należy wskazać następujące:

1) wysoki procent tzw. odpadu szkolnego, dwukrotność średniej krajów unijnych;

2) mocna polaryzacja rynku pracy, nisko wykwalifikowani potencjalni pracownicy oraz wysoko wykwalifikowani, pracujący poniżej swoich kwalifikacji;

3) relatywnie niskie znaczenie przypisywane pozimowi kształcenia zawodowego;

4) niski poziom zatrudnialności młodych ludzi, głównie z uwagi na brak znajomości języków obcych;

5) wysoki odsetek zatrudnienia tymczasowego, zwłaszcza wśród młodych ludzi, gdzie ponad $80 \%$ podejmuje takie formy zatrudnienia $\mathrm{z}$ konieczności, a nie z wyboru;

6) rosnący odsetek ofert pracy na niepełny etat (dotyczy ponad 50\% młodych ludzi, liczących że z czasem zaproponowana im zostanie praca na pełen etat);

7) utrudniony dostęp do rynku pracy dla grup zagrożonych wykluczeniem społecznym;

8) niski wskaźnik przedsiębiorczości i gotowości do samozatrudnienia wśród młodych Hiszpanów.

Wiele z tych systemowych słabości powiązanych jest z długoletnią tradycją subsydiowanego zatrudnienia i specjalnych form kontraktów dla młodych

${ }^{7}$ E. Lenart i in., Student advancement of graduates employability. Student Handbook on Employability, European Students' Union, Brussels 2014. 
bezrobotnych, wspierających ten sektor rynku pracy ${ }^{8}$. Jednak w ostatnich latach, zgodnie z wytycznymi Unii Europejskiej i rekomendacjami międzynarodowych organizacji, podejmowano w Hiszpanii wiele inicjatyw promujących przedsiębiorcze postawy, z uwzględnieniem przedsiębiorczości wśród młodych ludzi. Ważnym elementem kontekstu polityki edukacyjnej i rynku pracy jest decentralizacja Hiszpanii oraz relatywnie wysoka autonomia regionów upoważnionych do kreowania własnej polityki $i^{9}$.

Analizując sytuację $\mathrm{w}$ szkolnictwie wyższym, istotna różnica między Polską a Hiszpanią polega na tym, że uniwersytety hiszpańskie rozpoznają studentów nietradycyjnych jako odrębną kategorię uczących się. Dostrzegając różnicę w możliwości dostępu do szkolnictwa wyższego, adresuje się specjalne rozwiązania dla grup defaworyzowanych już od lat 70. XX wieku, kiedy to system szkolnictwa wyższego wprowadził alternatywne możliwości dostępu do kształcenia dla dojrzałych osób (powyżej 25. r.ż.), które nie spełniają formalnych warunków stawianych tradycyjnym studentom (zaliczony poziom szkoły średniej). Mogą one rozpocząć studia, jeśli zdadzą specjalny egzamin $\mathrm{w}$ formie testowej, tzw. access test. $\mathrm{W}$ ostatnich dekadach wielu studentów nietradycyjnych zrekrutowało się korzystając z tej ścieżki. Systemowe rozwiązania zwiększania dostępu zostały rozbudowane i pojawiły się nowe możliwości prawne, na mocy Dekretu Królewskiego z 2008 roku (Royal Decree 1892/2008, of the November 14th), który ustanowił rozwiązania promujące tzw. "pozytywną dyskryminację", gwarantując pewną pulę miejsc na uniwersytetach dla osób z grup wykluczonych, w tym osób z niepełnosprawnościami. Przewidziano również miejsca dla osób powyżej 40. roku życia, wykazujących się znaczącym doświadczeniem zawodowym w obszarze powiązanym z kierunkiem jaki pragną studiować, a także dla osób powyżej 45. roku życia, które zdadzą specjalny egzamin, dostosowany do ich możliwości.

Również inne akty prawne, jak na przykład Statut Studencki RD 1791/20104 (Statute of the University Student), wprowadziły nowe formy wsparcia dla studentów nietradycyjnych, tworząc nowe modele tutoringu lub udogodnienia dla studentów łączących naukę z pracą zawodową. Jednakże, rozwiązania te nie wydają się wystarczające i dostatecznie zindywidualizowane, ponieważ są integrowane z ogólną ofertą pomocową, adresowaną dla studentów tradycyjnych.

Wypracowane od lat 70. rozwiązania wyrównujące szanse edukacyjne i otwierające uniwersytety dla dojrzałych studentów są jednak zagrożone

${ }^{8}$ F.J. Calvo, M.F. Fernández, El contrato de 'primer empleo joven', [in:] La estrategia de emprendimiento y empleo joven en la ley, 11/2013: desempleo, empleo y ocupación juvenile, red. M.F. Fernández, F.J. Calvo, Albacete 2013, s. 257-307.

${ }^{9}$ J.T. Weishaupt, Central steering and local autonomy in public employment services. Analytical Paper, Luxembourg 2014. 
wskutek rozkwitu konserwatywnych modeli zarządzania w polityce hiszpańskiej w ostatnich latach, a także z uwagi na powiązania z efektami kryzysu gospodarczego i programami oszczędnościowymi. Dwie najpoważniejsze bariery, które pojawiły się w ostatnich latach, to znaczący wzrost opłat rekrutacyjnych za studia i radykalne zaostrzenie kryteriów przyznawania pomocy finansowej (stypendia socjalne i naukowe).

Specjalne rozwiązania, jeśli chodzi o zatrudnialność nietradycyjnych absolwentów, w systemie hiszpańskim nie funkcjonują. Można mówić, podobnie jak w przypadku Polski, o pewnych ogólnych ramach i działaniach adresowanych do szeroko rozumianych grup zagrożonych wykluczeniem i słabo radzących sobie na rynku pracy (kobiety, migranci, osoby z niepełnosprawnościami). Należy jednak podkreślić, że hiszpańskie uniwersytety wykazują się dużą aktywnością we wspieraniu wszystkich absolwentów w wejściu na rynek pracy i jak najwcześniejszej integracji świata uczelni ze światem pracy. Stosowane są tu zasadniczo dwa mechanizmy: 1) tworzenie ofert kształcenia odpowiadających na aktualne i bezpośrednie potrzeby rynku pracy (jest to, podobnie jak w przypadku Polski, konsekwencja wymogów procesu bolonskiego i nacisku na budowanie oferty edukacyjnej we współpracy z pracodawcami oraz koncentracja na rozwijaniu specyficznych kompetencji u studentów); 2) wsparcie doradztwa, orientacji i reorientacji zawodowej w czasach niepewnego i nieprzewidywalnego rynku oraz trudnych tranzycjach, których doświadczają absolwenci. Działania te w dużej mierze odzwierciedlają zaangażowanie uniwersytetów w ideę centralizowania i integrowania kształcenia z rynkiem pracy w taki sposób, by ułatwiać tranzycje absolwentom i wzmacniać ich szansę na płynne przejście do świata pracy ze świata uniwersytetu.

Na specjalną uwagę zasługuje także rosnące zaangażowanie uniwersytetów w praktyki i staże dla studentów oraz absolwentów, podobnie jak w kontekście polskiego szkolnictwa wyższego. Hiszpańskie uniwersytety nie mają wątpliwości, że jest to właściwa droga do wzmacniania zatrudnialności absolwentów oraz rozwijania deficytowych kompetencji przedsiębiorczych. Z tego powodu, dla większości kierunków na studiach pierwszego i drugiego stopnia praktyki i staże są obowiązkowe. W celu zwiększenia puli ofert wprowadzono nawet znaczące rozluźnienie przepisów, pozwalających przedsiębiorstwom na przyjmowanie studentów na praktyki i staże bezpłatne (co wcześniej nie było możliwe) oraz zwolniono firmy z obowiązku opłaty ubezpieczenia społecznego za studentów i absolwentów ${ }^{10}$. Spowodowało to protesty studentów, a zrzeszenia studenckie zaczęły wywierać nacisk na Ministerstwo Pracy w celu zmiany prawa i wprowadzenia minimalnych gwarancji socjalnych.

\footnotetext{
${ }^{10}$ Lenart i in., Student advancement of graduates employability.
} 
Podobnie jak w Polsce, można zaobserwować niesystemowe przykłady działań podejmowanych przez poszczególne uczelnie, wzmacniających komunikację uniwersytetów z lokalnymi rynkami pracy poprzez organizację targów pracy. Uniwersytety w Salamance, Sewilli, czy Saragossie organizują cyklicznie targi pracy (nawet kilka razy w roku), korzystając z różnych form interakcji - od kontaktów bezpośrednich po wirtualne. Cieszą się one niezmiennie dużą popularnością wśród studentów oraz absolwentów i postrzegane są jako doskonały sposób nawiązywania kontaktów z lokalnymi przedsiębiorcami oraz rozpoznawanie potrzeb regionalnych rynków pracy.

\section{Zatrudnialność, szkolnictwo wyższe i nietradycyjni studenci w polskich i hiszpańskich badaniach społecznych}

Zarówno polskie, jak i hiszpańskie prace badawcze na temat takich zjawisk, jak: „zatrudnialność” i „nietradycyjni studenci/absolwenci w szkolnictwie wyższym" pojawiły się wraz z postulatami formułowanymi przez krajowych i europejskich polityków edukacyjnych dopiero na początku XXI wieku. W Hiszpanii nastąpiło to w pierwszej dekadzie, w Polsce natomiast kilka lat później ${ }^{11}$. Pomimo tej dość krótkiej historii wskazanych tematów badawczych w obydwu krajach są one już rozpoznawane, a ich zawartość (formułowanie problemów badawczych, wyniki badań i ich interpretacje) można poddać analizie porównawczej.

W Hiszpanii i Polsce istnieje wiele raportów badawczych z interesującego nas w tym artykule obszaru, ale dotyczą one wyłącznie "osobnych" kwestii, to jest związanych z zatrudnieniem absolwentów, reformą szkolnictwa wyższego, bądź studentami nietradycyjnymi (częściej w literaturze hiszpańskiej niż polskiej). Te "osobne” tematy badawcze dominujące we wskazanym obszarze w obu krajach to: studenckie kompetencje budowania kariery zawodowej, przejście absolwentów ze świata uczelni do świata pracy, analizy polityk rekrutacyjnych współczesnych pracodawców oraz współpraca interesariuszy zewnętrznych $\mathrm{z}$ uczelnią. Istotną rolę $\mathrm{w}$ propagowaniu zintegrowanej problematyki badawczej (tj. obejmującej nietradycyjnego studenta/absolwenta - jego/jej zatrudnialność - uniwersytet - kadrę akademicką i pracodawców) odegrały międzynarodowe projekty badawcze realizowane zarówno w Pol-

${ }^{11}$ Por. A. García-Aracil, J.G. Mora, University-to-work transition among young Spanish higher education graduates: analytical approaches and results, Jornada internacional: La transición al trabajo de los jóvenes graduados europeos, Valencia 13 de mayo de 2004; E. Kurantowicz, A. Nizińska, Mikrohistorie studentów nietradycyjnych o uczeniu się w instytucjach kształcenia wyższego: o niezamierzonych skutkach uczestnictwa w projekcie europejskim PRILHE, [w:] Pedagogika: zakorzenienie i transgresja, red. M. Nowak-Dziemianowicz, P. Rudnicki, Wrocław 2011, s. 117-130. 
sce, jak i Hiszpanii (CHEER 1998-2000; REFLEX 2002-2004; PRILHE 2006-2008; RANLHE 2008-2011; INSTALL 2011-2014; EDUPRO 2014-2016; EMPLOY 2014-2017). Cele badawcze wymienionych projektów były zróżnicowane, ale odwoływały się głównie do teorii kapitału społecznego, teorii społeczno-kulturowych i krytycznych. Te podejścia badawcze i wykorzystane w większości projektów metody badań jakościowych pozwoliły na ujawnienie głosów studentów/absolwentów nietradycyjnych, pracodawców i kadry akademickiej, ich opinii w sprawie polityki zatrudnienia i wspierania grup mniejszościowych w szkolnictwie wyższym oraz na rynku pracy. Istotnym źródłem wiedzy porównawczej o studentach i warunkach ich codziennego życia są międzynarodowe raporty ${ }^{12}$, zaś w przypadku absolwentów - monitorowanie ich losów zawodowych ${ }^{13}$.

Zainteresowania zatrudnialnością absolwentów podzielają różne grupy badaczy - od ekonomistów, przez socjologów, psychologów i pedagogów. Każda z tych grup inaczej formułuje własne cele badawcze, ze względu na specyfikę dyscy pliny. W polskim i hiszpańskim kontekście badań naukowych pojawiają się więc takie kategorie analizy w obszarze nietradycyjnych studentów/absolwentów i rynku pracy, jak: wykluczenie społeczne, ubóstwo, bezrobocie, nierówności społeczne czy prekariat ${ }^{14}$. Podobieństwa w badaniach polskich i hiszpańskich badaczy dotyczą następujących tematów:

1) rola interesariuszy zewnętrznych i pracodawców w kształceniu wyższym i przystosowaniu kształcenia do potrzeb rynku pracy ${ }^{15}$;

2) rola praktyk i staży we wzmacnianiu zatrudnialności absolwentów. Definiuje się te formy jako najlepsze sposoby zdobywania doświadczenia zawodowego, co stanowi podstawowy element kariery, oceniany przez pol-

${ }^{12}$ Na przykład Eurostudent IV, 2012.

${ }^{13}$ J.M. Carot i in., La opinión de los graduados europeos sobre la universidad cinco años después de haber finalizado sus studios, Papers, 2011, 96(4), s. 1269-1285. W Polsce ogólnopolski monitoring losów zawodowych absolwentów obejmuje badanie przeprowadzone po raz pierwszy na grupie absolwentów z roku 2014 http:/ / ela.nauka.gov.pl/).

${ }^{14}$ Fundación FOESSA, 2014; M. Arnal, L. Finkel, P. Parra, Crisis, desempleo y pobreza: Análisis de trayectorias de vida y estrategias en el mercado laboral, Cuadernos de Relaciones Laborales, 2013, 31, 2, s. 281-311; F. Finnegan, B. Merrill, C. Thunborg (red.), Student Voices on Inequalities.

${ }^{15}$ G. Caballero, J.M. García, M.A. Quintás, El tiempo y la atención dedicados a los stakeholders: un análisis empírico aplicado a la empleabilidad del alumnado de la universidad española, Revista Europea de Dirección y Economía de la Empresa, 2008, 17(3), s. 43-60; G. Caballero, X.H. Vázquez, M. Quintás, Qué influencia tienen los stakeholders de la universidad española en la empleabilidad de sus alumnos? Propuestas de reforma, Cuadernos de Economía y Dirección de la Empresa, 2009, (38), s. 37-63; J. Hernández, M. Martín, A.B. Rabadán, Desajustes entre formación y empleo en el ámbito de las enseñanzas técnicas universitarias: la visión de los empleadores de la Comunidad de Madrid, Revista de Educación, 2013, 360, s. 244-267; J. Górniak (red.), Kompetencje Polaków a potrzeby polskiej gospodarki. Raport podsumowujący IV edycję badań BKL z 2013, Warszawa - Kraków 2014; M. Kocór, A. Strzebońska, M. Dawid-Sawicka, Rynek pracy widziany oczami pracodawców, Warszawa 2015. 
skich i hiszpańskich pracodawców w procesie rekrutacji, oraz jako ułatwiające przejście absolwentów z uczelni na rynek pracy ${ }^{16}$;

3) dominujące strategie poszukiwania pracy przez absolwentów. W obydwu kontekstach - polskim i hiszpańskim - są one dość podobne. Należą do nich: sieć kontaktów osobistych, rodzinnych i przyjacielskich, Internet oraz własna aktywność absolwentów (w Polsce ponad 70\% bezrobotnych poszukuje w ten sposób pracy). Najrzadziej absolwenci polskich i hiszpańskich uniwersytetów korzystają z usług instytucji publicznych oraz biur pośrednictwa pracy i nie są zadowoleni z ich funkcjonowania ${ }^{17}$. Co wydaje się bardzo interesujące, badania hiszpańskie pokazują, że wybór strategii znalezienia pracy zależy od ukończonego kierunku studiów. Wszystkie badania nad zatrudnialnością wskazują, że jest ona kształtowana zarówno przez cechy osobiste, zdolności, warunki życia studenta/absolwenta, a także nastroje społeczne związane z sytuacją na rynku pracy ${ }^{18}$;

4) zróżnicowanie terytorialne w dziedzinie zatrudnialności absolwentów. W Polsce problem ten najbardziej widoczny jest w dużych i małych miastach oraz regionach podmiejskich i wiejskich. Badacze hiszpańscy głównie koncentrują się na różnicach pomiędzy regionami ${ }^{19}$.

Warto również zauważyć, że w obydwu krajach istnieje mocny nurt badań krytycznych nad zatrudnialnością (employability), która obecnie staje się ważnym elementem "gry” między państwem, rynkiem pracy i szkolnictwem wyższym. Badacze krytyczni definiują fundamentalne dla tego związku pytania: czy uniwersytet ma być kolejną agencją zatrudnienia dla absolwentów, bądź w jakim zakresie uczelnia jest odpowiedzialna za ich zatrudnienie? Czy kształcenie według/zgodnie z potrzebami rynku pracy ma sens? Czy i jakie kompetencje/efekty kształcenia mają charakter uniwersalny dla pracodawców? Pytania te pojawiają się w opracowaniach obu grup badaczy i stają się kluczowe w kształtowaniu polityki uczelni wyższych wobec studentów/ab-

${ }^{16}$ J.C. Bernad, F. Marhuenda, A. Navas, Las prácticas en empresa como estrategia de enseñanza e inserción laboral: las empresas de inserción social, Revista de Educación, 2010, 351, s. 139-161; Staż. Sprawdź, zanim pójdziesz. Raport z wyników badania opinii studentów zrealizowanego w ramach kampanii społecznej.

${ }^{17}$ P. Martínez, M. Martínez, J. Pérez, Tutoría Universitaria: entorno emergente en la Universidad Europea. Un estudio en la Facultad de Educación de la Universidad de Murcia, Revista de Investigación Educativa, 2014, 32(1), s. 111-138, http://dx.doi.org/10.6018/rie.32.1.148411; J. Religa (oprac.), Bilans kapitału ludzkiego w Polsce. Najważniejsze wyniki V edycji badań BKL, 2014, www.bkl.parp. gov.pl

${ }^{18} \mathrm{~S}$. Rodríguez i in., Sobre la empleabilidad de los graduados universitarios en Catalunya: del diagnóstico a la acción, Revista de Educación, 2010, 351, s. 107-137; J. Religa (oprac.), Bilans kapitału ludzkiego w Polsce.

${ }^{19}$ J. Hernández, M. Martín, A.B. Rabadán, Desajustes entre formación y empleo, s. 244-267; M. Jelonek, K. Kasparek, M. Magierowski, Młodzi na rynku pracy - pracownicy, przedsiębiorcy, bezrobotni, Warszawa 2015. 
solwentów/ pracodawców ${ }^{20}$. Wiele prac badawczych coraz częściej wzmacnia ten dyskurs i podnosi kwestie wzajemnych relacji pomiędzy rynkiem pracy a uczelniami wyższymi oraz badań nad zjawiskiem zatrudnialności.

Jakie "luki” mają badania nad zatrudnialnością w obydwu krajach? Najczęściej są to pytania: co najbardziej podnosi zatrudnialność absolwentów w ocenie pracodawców i jakie wsparcie mogą otrzymać studenci/absolwenci, zwłaszcza nietradycyjni, od macierzystych uczelni, państwa i przyszłych pracodawców. W Hiszpanii nieliczni badacze tego zagadnienia definiują oczekiwania wobec absolwentów i ich luki kompetencyjne jako: znajomość języka obcego (szczególnie angielskiego), która jest konieczna już we wszystkich rodzajach pracy (także niskopłatnej i niewymagającej wysokich kwalifikacji); mobilność i doświadczenie międzynarodowe zdobyte na przykład przez uczestnictwo w Programie Międzynarodowej Wymiany Studentów Erasmus+ Mobility oraz umiejętności korzystania z Internetu, platform i mediów społecznościowych. W Polsce wymagania wobec absolwentów/pracowników nie ulegają drastycznej zmianie, nawet w przypadku (pozytywnych czy niekorzystnych) zmian na rynku pracy. Od kilku lat pracodawcy wskazują na kompetencje zawodowe, samoorganizacyjne i interpersonalne jako kluczowe przy ocenie kandydata do pracy ${ }^{21}$. Jednak, najbardziej interesujące są strategie rekrutacyjne pracodawców i ich interpretacja istniejących związków między zatrudnialnością absolwentów, uczelniami wyższymi a rynkiem pracy. To zagadnienie również w perspektywie porównawczej opisujemy w kolejnej części artykułu.

\section{Pracodawcy i zatrudnialność absolwentów uniwersytetów}

Badania wśród polskich i hiszpańskich pracodawców w projekcie EMPLOY były zrealizowane za pomocą otwartych wywiadów indywidualnych lub fokusowych. Ich celem było zrozumienie, jak pracodawcy definiują "zatrud-

${ }^{20}$ T. Bauman, Złudna efektywność uniwersytetu przedsiębiorczego, Ars Educandi, 2011, 8, s. 44-72; I. Brunet, I. Pastor, Tercera vía, Comisión Europea y estrategias de empleabilidad, ANDULI, Revista Andaluza de Ciencias Sociales, 2003, 3, s. 11-25; B.S. Lantarón, La empleabilidad en la Universidad Española, Journal for Educators, Teachers and Trainers, 2014, 5(2), s. 272-286; E. Potulicka, J. Rutkowiak, Neoliberalne uwikłania edukacji, Kraków 2010; P. Stańczyk, Przemoc i emancypacja. Ambiwalencja funkcji studiów zaocznych, Gdańsk 2008; B. Suárez-Lantarón, La Universidad española ante la empleabilidad de sus graduados: Estrategias para su mejora, Revista Española de Orientación y Psicopedagogía, 2014, 25, 2, s. 90-110; A. Santos, La política en manos de los empresarios: el imparable ascenso de la ideología del emprendedor, Papeles de Relaciones Ecosociales y Cambio Global, 2014, 127, s. 29-43.

${ }^{21}$ M. Kocór, A. Strzebońska, M. Dawid-Sawicka, Rynek pracy, s. 10. 
nialność" absolwentów nietradycyjnych, na co zwracają szczególną uwagę podczas procesów rekrutacyjnych, czy i jak polscy/hiszpańscy pracodawcy wzmacniają zatrudnialność swoich pracowników i na ile są świadomi zróżnicowania grupy absolwentów oraz specyfiki (mocnych, słabych stron) grupy nietradycyjnych studentów. Do badań wybrano pracodawców, którzy posiadali (nawet niewielkie) doświadczenie współpracy ze szkołami wyższymi, jak na przykład uczestnictwo w ciałach doradczych (np. w Polsce w radach programowych kierunków), współpraca w realizacji programów kształcenia (praktyki, staże) lub wspólnych projektów badawczo-rozwojowych. Zarówno w polskich, jak i hiszpańskich badaniach udział wzięło po 10 pracodawców reprezentujących różne sektory.

Pracodawcy najczęściej poszukują pracowników przez ogłoszenia prasowe, targi pracy, agencje zatrudnienia, urzędy pracy, biura karier, czy media społecznościowe. W celu jak najlepszego poznania kandydata i sprawdzenia jego predyspozycji do pracy, oprócz tradycyjnych rozmów i testów kwalifikacyjnych, coraz częściej stosują takie metody, jak wywiad kompetencyjny, testy praktyczne (work-sample tests), czy Assessment Center. Pracodawcy najczęściej sięgali do metod tradycyjnych, to jest analizy CV i bezpośredniej rozmowy z kandydatem do pracy. Większość strategii rekrutacyjnych polskich i hiszpańskich pracodawców ma raczej charakter "sita” (czyli poszukiwanie kandydata do pracy zgodnie z wymaganiami stanowiska) niż „inwestycji” (czyli poszukiwanie pracownika do częściowego lub pełnego przeszkolenia na dane stanowisko pracy) ${ }^{22}$.

Analiza wywiadów przeprowadzonych z polskimi pracodawcami potwierdza tezy, że kompetencje społeczne są kluczowe i zwiększają szanse absolwenta na rynku pracy. Formalne kompetencje zawodowe, takie jak ukończenie kierunku studiów adekwatnego do stanowiska jest podstawą, warunkiem koniecznym, ale nie czynnikiem decydującym o wyborze kandydata na miejsce pracy. Mówią oni (...) dotarliśmy do takiego etapu że sam dyplom uczelni (...) to jest formalność, która musi być spetniona (pracodawca, Polska, sektor publiczny).

Czego oczekują polscy pracodawcy od absolwentów? Przede wszystkim poszukują ciekawej osobowości, „człowieka z pasją”, z „otwartą głową". Zatem można powiedzieć, że poszukują pracownika zaangażowanego, gdzie pasja jest rozumiana jako element budowania relacji, jako podstawa kreatywności, czy też jako element łączący wiedzę i umiejętności w procesie praktykowania. Równie ważne jest doświadczenie. Jednakże, pracodawcy są świadomi, że młody człowiek szukający pracy po studiach nie musi mieć doświadczenia zdobytego na takim samym czy podobnym stanowisku pracy.

${ }^{22}$ M. Kostera, Zarzadzanie personelem, Warszawa 1999. 
Dlatego, bardzo ważna jest dla nich dodatkowa aktywność studenta, jak na przykład wolontariat, praca podczas wakacji, odbyte staże. Doświadczenie bycia $\mathrm{w}$ praktyce, działania podjęte $\mathrm{w}$ konkretnych zawodowych sytuacjach są traktowane jako "potwierdzenie” między innymi takich kompetencji, jak umiejętność nawiązywania i utrzymywania kontaktów, zdolność do współpracy, radzenia sobie $w$ trudnych sytuacjach.

Pracodawcy w Polsce zwracają również uwagę na spójność i zgodność pomiędzy tym co zostało zawarte $\mathrm{w} \mathrm{CV}$, a tym jak na rozmowie kwalifikacyjnej prezentuje się kandydat - czy jest świadomy swoich umiejętności i potrafi o nich opowiadać. Podkreślano również znaczenie umiejętności pracy w grupie i organizowania pracy oraz ciekawość świata.

Wśród hiszpańskich pracodawców (małych i dużych przedsiębiorstw) najczęściej wymienianą kompetencją absolwentów jest umiejętność adaptacji do środowiska pracy i sytuacji na rynku pracy, często nazywana też elastycznością, wszechstronnością kandydata do pracy i uszczegółowiana jako zdolność do odnalezienia się na każdym stanowisku pracy, podejmowania różnych zadań. Zarówno współczesne przedsiębiorstwa, jak i rynek pracy są zmienne, podlegają raptownym przekształceniom (z przyczyn często niezależnych od pracodawców), więc absolwent musi posiadać umiejętności pozwalające na zarządzanie tą zmianą.

Tak rozumiana kompetencja adaptacyjności jest blisko powiązana z umiejętnością szybkiego uczenia się i mocną motywacją do podejmowania nowych wyzwań, twórczego i otwartego podejścia do zadań i ich realizacji.

Czego przede wszystkim wymagamy od kandydata, to pokory w codziennym uczeniu się i bycia świadomym, że nigdy nie przestanie się uczyć, bez względu na to ile formalnych dyplomów posiada (Rafael, dyrektor regionalny, sektor prywatny).

Całożyciowe uczenie się w miejscu pracy ma związek z coraz bardziej społecznym charakterem procesów pracy. Osłabieniu ulegają takie cechy pracy, jak stabilność, przewidywalność i rutynowe metody działania. Dobry pracownik to nie ten, który sprawnie operuje raz wyuczonymi kompetencjami. Pracodawcy poszukują pracowników gotowych do podejmowania nowych wyzwań, będących w ciągłej gotowości do uczenia się.

Drugą grupą kompetencji oczekiwanych przez hiszpańskich pracodawców są kompetencje społeczne, komunikacyjne i związane z pracą w zespolach pracowniczych. W wypowiedziach osób badanych podkreślane są także kompetencje zawodowe/branżowe, komputerowe i doświadczenie pracy w środowisku międzynarodowym. Hiszpańscy pracodawcy podkreślają jako pożądaną cechę u młodych pracowników ich identyfikację z firmą, miejscem pracy, zaangażowanie w rozwój firmy. 
Zarówno polscy, jak i hiszpańscy pracodawcy podkreślają, że staże są jedną z najlepszych form zdobycia doświadczenia, uczenia przez praktykę i sprawdzenia się kandydatów w środowisku pracy, a w konsekwencji zdobycia miejsca pracy.

Wierze, że staże sa kluczem do wejścia na rynek pracy; poza tym najważniejsze jest to, że mentoring prowadza osoby, ktorym rzeczywiście zależy na Twoim uczeniu się, a nie tylko na tym, że jesteś niskopłatnym pracownikiem (Rafael, sektor prywatny).

Ważna jest jednak otwartość stażystów, praktykantów na różne doświadczenia, uczenie się i korzystanie z nich dla własnego rozwoju.

Tak, jesteś tutaj od 8 do 16 i jesteś po to żeby robić jak najwięcej. A jak się okazuje, $\dot{z}$ e trzeba przedrzeć bilet na bramce to stysze; ",- no, ale jak? Ja jestem już przecież po maturze”. Trudno wyttumaczyć ",stażyście”, że w trakcie przedzierania biletu można się więcej dowiedzieć niż w trakcie oglądania YouTubéa (Marek, sektor samorządowy).

Pracodawcy mają także szeroką wiedzę na temat istniejących „wypaczeń" idei staży i to zarówno strukturalnych, prawnych, jak i organizacyjnych. To one w dużej mierze skazują absolwentów na włączenie do społecznej kategorii prekariatu.

Uważam, że idea staży, praktyk, grantów "dla absolwentów" jest źle zrozumiana i wiele organizacji robi z tych form zty użytek (....) "stażyści, grantobiorcy" sa dobrze przygotowani, maja ukończone studia, wydali własne pieniadze na kształcenie (...) a sa przyjmowani na stanowiska, gdzie jest praca, której nikt z firmy nie lubi, nie chce wykonywać (...) przedtużamy kontrakty stażowe na tych samych warunkach (...) jestem za tym, aby staże, granty u pracodawców byty krótko-, średnioterminowe i dawaty gwarancje przynajmniej w 80\% dalszego zatrudnienia. Obecnie bierzemy tych absolwentów na staż na trzy lata, bez żadnego zabezpieczenia ich dalszej kariery, na program nieefektywny $i$ demotywujacy młodych ludzi (...) (Álvaro, HR manager, korporacja międzynarodowa).

Rozumienie „zatrudnialności”, kapitału "zatrudnialności” absolwenta przez pracodawców w Polsce i Hiszpanii jest bardzo zbliżone. Dla pracodawców „zatrudnialność” absolwentów to przede wszystkim kapitał, który absolwenci wnoszą do miejsca pracy (osobowość, wiedza i kompetencje, sieci społeczne). To głównie z tej perspektywy (miejsca pracy i potrzeb środowiska pracy) pracodawcy biorący udział w badaniach definiowali wartość „employability". 
(...) Ważne jest, czy oprócz studiów kierunkowych ma jeszcze jakieś inne kursy, studia podyplomowe, czy ma jakieś inne kompetencje i umiejętności które można będzie maksymalnie wykorzystać w pracy, żeby nie zatrudniać jeszcze dodatkowo kogoś $z$ zewnatrz, $z$ dodatkowych firm, żeby wykorzystać - tak powiem w cudzystowie tego nauczyciela (...). My zadajemy pytanie czy potrafi gotować. Jeśli tak, to super, bo będzie go można wykorzystać do zajęć praktycznych, jeżeli posiada jeszcze umiejętności artystyczne, to skorzystaja i dzieci, i placówka przy dekoracji, przy różnego rodzaju festynach, zabawach karnawałowych (...). Ja zawsze szukam osoby. Kwalifikacje formalne sa bardzo ważne, natomiast świadomość przez osobę swoich mocnych stron, swoich atutów... Ja zawsze się pytam, co pani może zaoferować szkole, uczniom, co pani jeszcze umie i potrafi, w jakich obszarach chciałaby się pani realizować w szkole (Hanna, sektor publiczny).

Warto podkreślić, że kandydaci do pracy/absolwenci starając się o pracę w nowej profesji, musza wspomnieć o wszystkich swoich poprzednich doświadczeniach $i$ kompetencjach. To, że jest to dla kandydata nowy zawód, nie znaczy, że przychodzi on/ona do pracodawcy "z pustymi rękami”, jego/jej kompetencje nie są stracone, one zawsze mogą być przydatne, zwiększone i wzbogacone także w nowym miejscu pracy (Domingo, sektor samorządowy).

Ważnym obszarem rozpatrywanym przez pracodawców w kontekście zatrudnienia kandydata jest jego/jej kapitał tożsamościowy ${ }^{23}$. Osobowość absolwenta, czyli świadomość samego siebie i swoich możliwości, kompetencji, uzdolnień, doświadczeń, jak i przedsiębiorczość, zaangażowanie, pasja, ogólna aktywność życiowa itp. stają się tym, co wyróżnia kandydata do pracy wśród innych. Kandydat musi mieć taką osobowość (...) która pozwalałaby mu wejść do biura i powiedzieć wiem to i to, moge w tym pomóc, albo jakąkolwiek przedstawić od siebie propozycje (Maciej, sektor samorządowy).

Zatrudnialność absolwenta wzrasta wraz z ilością pozaformalnych doświadczeń edukacyjnych i zawodowych. Uprzednie doświadczenia absolwentów są dla pracodawców źródłem wiedzy i umiejętności, które absolwent „przenosi” do miejsca pracy i wykorzystuje je w praktyce. W ten sposób pracodawcy stają się promotorami uczenia się nieformalnego i pozaformalnego, doceniają jego efekty w procesie rekrutacji.

(...) bo zatóżmy, że mamy $10 \mathrm{CV}$ i chcemy wybrać ze 3 osoby na rozmowę, więc szybko się przerzuca, kwalifikacje sa obligatoryjne, bo nie będzie się starat o prace ktoś kto nie ma kwalifikacji, więc patrzymy na te dalsze punkty CV (Ewelina, sektor publiczny). Zwracam uwagę na to, jakie miaty praktyki; dla mnie atutem jest, jeśli ta osoba miata kontakt z osobami z niepetnosprawnościa, nie tylko w postaci praktyk,

${ }^{23}$ T. Schuller i in., Zarzadzanie personelem, Warszawa 2004. 
ale czasem w ramach wolontariatu, jakiejś innej formy aktywności (Wioletta, sektor pozarządowy).

(...) kiedy absolwent wykazuje, że łaczył studia z jakaśs praca zawodowa, to podczas rekrutacji oceniamy to bardzo wysoko. Wiemy, że sa to osoby dojrzate, potrafiace ciężko pracować i są odpowiedzialne (...) (Angel, sektor międzynarodowy).

Jak pokazują wyniki badań, niewątpliwie pracodawcy w procesie rekrutacji oceniają także tzw. kapitał społeczny kandydata. Biorą pod uwagę sieć jego/jej kontaktów społecznych (realny i wirtualny), umiejętności korzystania z wiedzy innych, podejmowane wspólne działania z innymi, zainteresowanie światem, zaangażowanie. Ten zasób zatrudnialności jest oceniany przez pracodawców jako dobra podstawa do „odnalezienia się” w nowym środowisku, miejscu pracy absolwentów/kandydatów; uprzednie doświadczenia gwarantują, że młody pracownik skupi się na pracy, a nie na sobie w nowej roli.

\section{Zakończenie}

Konfrontacja studentów/absolwentów nietradycyjnych z rynkiem pracy jest trudna i zgodnie $\mathrm{z}$ wynikami badań międzynarodowych ${ }^{24}$, nierówności i marginalizacja doświadczone w szkołach wyższych (ze względu na cechy nietradycyjności) przenoszone są na rynek pracy. W Polsce i Hiszpanii częściej obserwujemy mechanizm powrotu do edukacji wyższej jako koła ratunkowego przed marginalizacją i wykonywaniem pracy poniżej kwalifikacji, a często poczucia godności i brakiem jej uznania. W Hiszpanii uniwersytety są miejscem "przetrwania” gorszych czasów na rynku pracy i wykorzystania tego okresu na nabywanie kompetencji operacyjnych, które zdaniem absolwentów będą przydatne na każdym rynku pracy. Oczekiwania polskich i hiszpańskich pracodawców wobec absolwentów dotyczą dwóch grup kompetencji osobowych i profesjonalnych w obszarze zarówno postaw, jak i konkretnych umiejętności. Ciekawe (i odmienne w różnych krajach) są sposoby rozpoznawania tych kompetencji przez pracodawców. W Polsce najczęściej pracodawcy odwołują się do własnej intuicji, doświadczenia i ogólnego wrażenia, jakie zrobi kandydat do pracy lub jej/jego CV. W obu krajach ocenie przy rekrutacji podlegają kompetencje związane z całożyciowym i pozaformalnym/nieformalnym uczeniem się. wań.

${ }^{24}$ Por. F. Finnegan, B. Merrill, C. Thunborg (red.), Student Voices; ranlhe.dsw.edu.ploczeki- 
Perspektywy współistnienia uniwersytetów i gospodarki/rynku pracy są podobne w obydwu krajach. Charakteryzuje je dążenie do zachowania autonomii uniwersytetów i walka o nieekonomizowanie jego działalności oraz utrzymanie jako dobra publicznego ${ }^{25}$. Wciąż interesujące jest pytanie o perspektywę postrzegania przez pracodawców nie tyle absolwentów, co uniwersytetu jako instytucji kultury, która powiązana jest z zupełnie innym światem niż rynek pracy.

Wydaje się, że partnerska koegzystencja i racjonalne działanie na rzecz świata pracy byłoby możliwe, pod pewnymi warunkami. Ted Fleming ${ }^{26}$ odczytując myśl Habermasa dla edukacji, wskazuje, że uniwersytety kształcąc wykwalifikowanych pracowników, mogą także działać na rzecz dobra społecznego, czy też, odwołując się do języka teorii krytycznej, ochrony „świata życia", nie tylko na rzecz interesów systemu (aparatu państwa i mechanizmów gospodarki). Podkreśla jednak, że niezbędna jest zmiana paradygmatu koncepcji „bycia wykwalifikowanym”, gdyż nie może tu jedynie chodzić o dostarczenie praktycznych umiejętności. Bycie wykwalifikowanym to posiadanie także kwalifikacji społecznych, wrażliwość na dobro innych ludzi, troska o słabszych. Elementy te powinny stać się częścią świata pracy, a taki model rozwoju zawodowego z powodzeniem może być rozwijany na uniwersytetach $\mathrm{w}$ ramach szerszej misji budowania społeczeństwa obywatelskiego i wzmacniania demokracji. Jak wskazuje Habermas,

(...) rozwój zawodowy wymaga kombinacji kompetencji i zdolności do uczenia się, pozwalającej na dokładne poradzenie sobie z niepewną wiedzą techniczną oraz wrażliwości na kontekst, opartej na rzetelnych informacjach zdolności do politycznego oporu względem absurdalnych funkcjonalnych aplikacji czy kontroli praktykowanej przez jednostkę wiedzy ${ }^{27}$.

Bycie wykwalifikowanym w Habermasowskim rozumieniu staje się zatem bliskie byciu refleksyjnym praktykiem, czyniąc z edukacji, także tej na rzecz świata pracy, szerszy projekt społeczny. Jak podkreśla Fleming,

(...) byłoby to niezwykle ekscytujące, gdyby uniwersytety właśnie tak rozumiały działania na rzecz rozwoju profesjonalnego i zawodowego ${ }^{28}$.

Analizując materiał oraz wypowiedzi pracodawców polskich i hiszpańskich, wydaje się, że możliwe jest myślenie o takiej właśnie współpracy

${ }^{25}$ T. Bauman, Złudna efektywność, s. 65-67.

${ }^{26}$ T. Fleming, Skazani na uczenie się. Habermas, uniwersytety $i$ uczace się społeczeństwo, [w:] Habermas, teoria krytyczna i edukacja, red. M. Fleming, Wrocław 2012.

${ }^{27}$ J. Habermas, Towards a Rational Society: Student Protest, Science and Politics, Boston, MA 1970, s. 47, za: T. Fleming, Skazani na uczenie się.

${ }^{28}$ Tamże, s. 142. 
uniwersytetów z szeroko rozumianym „rynkiem” i jego mandatariuszami, jednak pracodawcy, jak i absolwenci, potrzebują edukacji, która zainicjuje nowy, racjonalny dyskurs, kontestujący logikę systemu i wprowadzający elementy wartości zaczerpnięte ze świata życia. Ważnym partnerem i znaczącym graczem w budowie takiego dyskursu powinno, obok uniwersytetów i pracodawców, stać się państwo, słusznie postrzegające edukację jako jeden z wielu systemów wspierających gospodarkę. Jednak, jak podkreśla Fleming, „polityka edukacyjna oparta tylko na potrzebach rynku jest do głębi skażona" 29. Zmiana tego myślenia i nowe, bardziej odpowiedzialne, podejście państwa wydaje się pierwszym warunkiem otwarcia nowego dyskursu i może ukształtować nowe rozumienie pojęcia "zatrudnialności”, uwzględniając, obok sprawstwa jednostki, także uwarunkowania społeczne i strukturalne, konstruowane przez państwo i gospodarkę.

\section{BIBLIOGRAFIA}

Arnal M., Finkel L., Parra P., Crisis, desempleo y pobreza: Análisis de trayectorias de vida y estrategias en el mercado laboral, Cuadernos de Relaciones Laborales, 2013, 31, 2.

Bauman T., Złudna efektywność uniwersytetu przedsiębiorczego, Ars Educandi, 2011, 8.

Bernad J.C., Marhuenda F., Navas A., Las prácticas en empresa como estrategia de enseñanza e inserción laboral: las empresas de inserción social, Revista de Educación, 2010, 351.

Brunet I., Pastor I., Tercera vía, Comisión Europea y estrategias de empleabilidad, ANDULI, Revista Andaluza de Ciencias Sociales, 2003, 3.

Caballero G., García J.M., Quintás M.A., El tiempo y la atención dedicados a los stakeholders: un análisis empírico aplicado a la empleabilidad del alumnado de la universidad española, Revista Europea de Dirección y Economía de la Empresa, 2008, 17(3).

Caballero G., Vázquez X.H., Quintás M., Qué influencia tienen los stakeholders de la universidad española en la empleabilidad de sus alumnos? Propuestas de reforma, Cuadernos de Economía y Dirección de la Empresa, 2009, 38.

Calvo F.J., Fernández M.F., El contrato de ,primer empleo joven', [in:] La estrategia de emprendimiento y empleo joven en la ley, 11/2013: desempleo, empleo y ocupación juvenile, red. M.F. Fernández, F.J. Calvo, Editorial Bomarzo, Albacete 2013.

Carot J.M., Conchado A., Mora J.G., Vila L.E., La opinión de los graduados europeos sobre la universidad cinco años después de haber finalizado sus studios, Papers, 2011, 96(4).

Czubak-Koch M., González Monteagudo J., Nizińska A., Padilla-Carmona T., Między uniwersytetem a światem pracy. Tranzycje w narracjach studentów polskich i hiszpańskich, Dyskursy Młodych Andragogów, 2017, 18.

EHEA 2012, Bucharest Communiqué: Making the Most of Our Potential: Consolidating the European Higher Education Area 26-27 April 2012; https://media.ehea.info/file/2012_Bucharest/67/3/Bucharest_Communique_2012_610673.pdf

Fernández M.F., Calvo F.J. (red.), La estrategia de emprendimiento y empleo joven en la ley 11/2013: desempleo, empleo y ocupación juvenile, Editorial Bomarzo, Albacete 2012.

${ }^{29}$ Tamże, s. 142. 
Finnegan F., Merrill B., Thunborg C. (red.), Student Voices on Inequalities in European Higher Education, Routledge, London - New York 2014.

Fleming T., Skazani na uczenie się. Habermas, uniwersytety i uczace się społeczeństwo, [w:] Habermas, teoria krytyczna i edukacja, red. M. Fleming, Wydawnictwo Naukowe DSW, Wrocław 2012.

Fundación FOESSA, VII Informe sobre exclusión y desarrollo social en España, 2014, Available at: http://www.foessa2014.es/informe/

García-Aracil A., Mora J.G., University-to-work transition among young Spanish higher education graduates: analytical approaches and results, Jornada internacional: La transición al trabajo de los jóvenes graduados europeos, Valencia 13 de mayo de 2004.

Górniak J. (red.), Kompetencje Polaków a potrzeby polskiej gospodarki. Raport podsumowujacy IV edycję badań BKL z 2013, Polska Agencja Rozwoju Przedsiębiorczości, Warszawa Kraków 2014.

Habermas J., Towards a Rational Society: Student Protest, Science and Politics, Beacon Press, Boston, MA 1970.

Hernández J., Martín M., Rabadán A.B., Desajustes entre formación y empleo en el ámbito de las enseñanzas técnicas universitarias: la visión de los empleadores de la Comunidad de Madrid, Revista de Educación, 2013, 360.

Jelonek M., Kasparek K., Magierowski M., Młodzi na rynku pracy - pracownicy, przedsiębiorcy, bezrobotni, Na podstawie analizy kierunków kształcenia zrealizowanej w 2014 roku w ramach V edycji projektu Bilans Kapitału Ludzkiego, Edukacja a rynek pracy - tom IV, Polska Agencja Rozwoju Przedsiębiorczości, Warszawa 2015.

Kocór M., Strzebońska A., Dawid-Sawicka M., Rynek pracy widziany oczami pracodawców, PARP, Warszawa 2015.

Kostera M., Zarzadzanie personelem, PWE, Warszawa 1999.

Kurantowicz E., Nizińska A., Mikrohistorie studentów nietradycyjnych o uczeniu się w instytucjach ksztatcenia wyższego: o niezamierzonych skutkach uczestnictwa w projekcie europejskim PRILHE, [w:] Pedagogika: zakorzenienie i transgresja, red. M. Nowak-Dziemianowicz, P. Rudnicki, Wydawnictwo Naukowe DSW, Wrocław 2011.

Kurantowicz E., Nizińska A., Equality and improving retentions practices for non-traditional students in Poland, [w:] Student Voices on Inequalities in European Higher Education, red. F. Finnegan, B. Merrill, C. Thunborg, Routledge, London - New York 2014.

Lantarón B.S., La empleabilidad en la Universidad Española, Journal for Educators, Teachers and Trainers, 2014, 5(2).

Lenart E. i in., Student advancement of graduates employability. Student Handbook on Employability, European Students' Union, ESU, Brussels 2014.

Martínez P., Martínez M., Pérez J., Tutoría Universitaria: entorno emergente en la Universidad Europea. Un estudio en la Facultad de Educación de la Universidad de Murcia, Revista de Investigación Educativa, 2014, 32(1), s. 111-138, http:/ / dx.doi.org/10.6018/rie.32.1.148411.

Ministerio de Educación, Cultura y Deporte, Panorama de la educación. Indicadores de la OCDE 2014, Informe español, Secretaría General Técnica del MECD, Madrid 2014, Avalaible at http://educalab.es/documents/10180/15676/panorama-de-la-educacion-2014informe-espanol-05-sep-.pdf/752b8a1c-ff07-46c3-97cd-7644b4691337.

OECD 2007, Poland must accelerate reform of tertiary education, http://www.oecd.org/poland/polandmustacceleratereformoftertiaryeducationoecdsays.htm

Potulicka E., Rutkowiak J., Neoliberalne uwiktania edukacji, Oficyna Wydawnicza Impuls, Kraków 2010.

Religa J. (oprac.), Bilans kapitatu ludzkiego w Polsce. Najważniejsze wyniki V edycji badań BKL, 2014, www.bkl.parp.gov.pl 
Rodríguez S., Prades A., Bernáldez L., Sánchez S., Sobre la empleabilidad de los graduados universitarios en Catalunya: del diagnóstico a la acción, Revista de Educación, 2010, 351.

Santos A., La política en manos de los empresarios: el imparable ascenso de la ideología del emprendedor, Papeles de Relaciones Ecosociales y Cambio Global, 2014, 127.

Schuller T. i in., The benefits of learning. The impact of education on health, family and social capital, RoutledgeFalmer, London 2004.

Stańczyk P., Przemoc i emancypacja. Ambiwalencja funkcji studiów zaocznych, Wydawnictwo Uniwersytetu Gdańskiego, Gdańsk 2008.

Staż. Sprawdź, zanim pójdziesz, 2014, Raport z wyników badania opinii studentów zrealizowanego w ramach kampanii społecznej. www.stazeipraktyki.pl

Suárez-Lantarón B., La Universidad española ante la empleabilidad de sus graduados: Estrategias para su mejora, Revista Española de Orientación y Psicopedagogía, 2014, 25, 2.

Weishaupt J.T., Central steering and local autonomy in public employment services. Analytical Paper, Directorate-General for Employment, Social Affairs and Inclusion - European Commission, Luxembourg 2014. 